earth and the mean density of the earth as a whole, viz. : 2.67 and 5.576 , in place of 2.8 and 56.6 .

In August, 1913, two members of Dr. de Filippi's Karakoram Expedition swung their pendulums at Dehra. Dun, and thus a new independent value for gravity at Dehra Dun will be obtained when the expedition has returned to Genoa.

No officer being available, the determination of astronomical latitudes was not undertaken during this season.

Work was carried on in the principal triangulation, and twenty-two triangles of the Sambalpur series were observed, the standard of precision being well maintained in spite of the difficult and inhospitable character of the country traversed. A network was also observed as the control for a large-scale survey of Bombay island, and as a further stage a traverse network of considerable precision was utilised. Permanent marks were placed on brass plugs which were built into masonry a foot below ground, and a special device was introduced for accurately centring the theodolite over the mark. Linear measurements were made with a Ioo-ft. steel tape, which was strained by means of weights suspended over pulleys. The precision of the lines of the traverse network when adjusted to triangulated poir.ts is given as $\mathrm{I}$ in $\mathrm{I} 2,000$.

Some 180 miles of the Indo-Russian triangulation connection, which had been reconnoitred in the previous year, were observed, and the work satisfactorily concluded.

In levelling details are given of carrying lines, of levelling across rivers, both by the "target" and by the "vertical angles" methods, and their respective advantages are discussed.

In the winter of $19 \mathrm{I}_{2-1} 3$ a delimitation of the boundary between Nepal State and Naini Tal district was carried out. The boundary consisting of three straight lines joining. four predetermined points in forested country, it was found most convenient to run an accurate traverse near and approximately parallel to the boundary line, so that from the traverse points could be located on the boundary line, and be determined. The result was quite satisfactory, and boundary pillars were erected along the line.

Dehra Dun having been dispensed with as a meteorological station, the forenoon and afternoon observations have been discontinued, and others at 2 p.m. (standard time) have been substituted. With similar simultaneous observations taken at Mussoorie, it is hoped to gain information bearing on terrestrial refraction which will be useful in the work of the survey.

Besides the points which have been mentioned there is much detailed information of value and importance to surveyors and geodesists in these volumes, which represent a large amount of work of a high standard carried out during the period under review.

H. G. L.

THE FLY PROBLEM.

I $\mathrm{N}$ a pamphlet published by the Zoological Society, entitled, "The Fly Campaign," and in a public lecture delivered at the Zoological Society's offices, Prof. Lefroy has dealt with the problem of the housefly and its allies, less from the purely scientific point of view than from the practical and economical aspect.

The pamphlet discusses flies generally, their importance and occurrence; the life-history of the house-fly is dealt with in detail; the eggs and where they are laid, the maggot, its habits, appearance, and its migration; the pupæ, the adult, its appearance, food, reproduction and the total period of its life.

NO. $238 \mathrm{I}$, VOL. 95].
A separate section describes the feeding habits of the fly, to show why and how it is such a carrier of disease, and what a repulsive intruder it is to houses; the hibernation and flight of flies is separately discussed, and a section deals with other flies than the house-fly which are found in houses.

Dr. C. J. Martin has written a section on flies as carriers of disease, which need not be summarised in view of the article on this subject in NATURE of May I3.

The pamphlet then deals with "Methods of Destruction," including the treatment of "tips" and manure, the protection of hospitals and houses, and the use of fly-traps. It concludes with a bibliography.

In his lecture at the Zoological Society's offices on June 2 Prof. Lefroy illustrated his remarks with lantern slides, largely made from the posters and illustrations used in the Fly Exhibition at the Zoological Society's gardens; these bring home vividly what flies do, how they actually feed, what the connection is between the fly feeding on human excreta and the spread of typhoid or summer diarrhœa.

In the lecture Prof. Lefroy expressec his personal opinion on many points, and especially on the question of the treatment of manure. Elaborate experiments are in progress, and already a method has been obtained which is one-third the cost of borax and water, and of far more general application. Naturally this has to be elaborately tested, but the lecturer was extremely hopeful of a solution of this problem, by far the most important in regard to the prevention of flies.

Equally elaborate experiments are in hand with regard to baits, with great promise of success; and success means a good bait that may be obtained and used in the campaign this summer.

Prof. Lefroy's lecture was illustrated by more than sixty lantern slides, many made from large wall pictures prepared for the Fly Exhibition by Miss Bertha Reid. Arrangements have been made to reproduce the lecture with the slides at any town in England that wishes it. The exhibition at the Zoological Society's gardens is popular, and will bring home to many the importance of flies and the simple ways of dealing with them.

\section{JAMAICA AS A CENTRE FOR BOTANICAL RESEARCH IN THE TROPICS.}

$\mathrm{NO}$ botanist should be content until he has visited some tropical area, and studied its flora on the spot. The tropical region most readily accessible from Great Britain lies in the West. Indies; and as Jamaica now offers special facilities at the Cinchona station, recently leased by the Jamaican Government to a committee of the British Association, the time is opportune for explaining the advantages it can provide.

The public gardens controlled by the Jamaican Department of Agriculture are seven in number. Of these only three are botanic gardens in the strict sense, viz., the Hope Gardens near Kingston, the Castleton Garden, and the Cinchona Plantation, or Hill Gardens, in the Blue Mountains.

The first of these lies on the Liguana Plain, just beneath the foothills of the Port Royal range, at an elevation of $650 \mathrm{ft}$., and about six miles from Kingston. It comprises an area of 200 acres, with a mean annual temperature of $76^{\circ} \mathrm{F}$., and average rainfall of 54.5 in. The gardens contain a large and varied collection of typical plants of the tropics, together with economic and ornamental plants, and many species of academic interest. The office, which constitutes the headquarters of the Agricultural Department, contains a good working library, and an in- 
valuable herbarium representative of the Jamaican flora. These, together with the willing help of the superintendent, Mr. W. Harris, greatly facilitate determinations of species. The laboratories of the island chemist and of the Government micro-biologist, where, by the courtesy of the Government, reagents may be purchased at cost price, are located within easy reach of the gardens.

Castleton Garden occupies a tract of undulating ground on the left bank of the Wag-Water River, nineteen miles north-west of Kingston, on the road leading to Annotto Bay on the north coast. The average elevation of the garden is $500 \mathrm{ft}$., the annual mean temperature is $76^{\circ} \mathrm{F}$, and the average rainfall II 7 in. Though much smaller, and from an economic point of view less important than the principal garden at Hope, Castleton is, if anything, of greater interest to the botanical visitor. The climatic conditions are highly conducive to the growth of luxuriant vegetation; for not only is the rainfall more than twice as high as at Hope, but the atmospheric humidity is also far greater, particularly at night time, the dews being extraordinarily heavy. One of the most striking features of the garden is the collection of palms grouped artistically around a centre water-lily pond. Other families of Angiosperms that are particularly well represented are the Moraceæ, the Cæsalpinioid, and other Leguminosæ, and the Lecythidaceæ. Groups of Cycads and of Marattiaceous and Cyatheaceous ferns, bamboo-groves, clumps of tall Scitamineæ, Aroid root-climbers, and the ubiquitous epiphytic Bromeliads and epiphyllous Lichens and Hepatics are other prominent elements in a thoroughly tropical scene.

The Hill Gardens-formerly the Cinchona Plantation, and still generally known as Cinchona-are placed on one of the southern spurs of the Blue Mountains, at an altitude of $4900 \mathrm{ft}$. As the crow flies, they are about fifteen miles from Kingston, in a northerly direction; but by road the distance is somewhat greater. The scenery, especially on the latter part of the route, is beautiful in the extreme, and the vegetation varied and interesting, although up to about $4000 \mathrm{ft}$. it has been considerably modified by cultivation.

The Hill Gardens were at one time the headquarters of the botanical department, and the centre of extensive Cinchona plantations, but are now the least important, economically, of the agricultural and botanical stations maintained by the Jamaican Government. The garden proper lies on the steep terminal slope of a spur, which projects in a southerly direction from the central chain of the Blue Mountains, at a point situated nearly midway between the two high passes known respectively as Morce's Gap and Newhaven Gap. Except to the northward, where the ground rises steeply for some distance, magnificent views are obtained in every direction. Due south, one looks across the deep Yallahs valley, over the Port Royal Hills, towards Kingston Harbour, the great Palisadoes reef, which forms its natural breakwater, and the open sea. On the west and southwest, John-Crow Peak and Catherine Peak stand out prominently above many lesser hills. Eastwards, beyond the Green River valley, rise Sir John Peak $(6 \mathrm{roo} \mathrm{ft}$.) and the twin summits of the Blue Mountain Peak (both more than $7000 \mathrm{ft}$.), the latter almost always wrapped in mist except at dawn.

The Cinchona dwelling-house is a substantial singlestorey building, of bungalow type, containing two sitting-rooms and four bedrooms, besides litchen, scullery, and servants' quarters. It is this house that is now let to a committee of the British Association, and would be available for scientific visitors. It is No. $238 \mathrm{I}$, VOL. 95] furnished and kept in excellent repair, and is cleansed and aired at regular intervals, so as to be ready for occupation at any moment. Close by are four or five wooden sheds, two of which stand on the same terrace as the house, the rest being situated at a somewhat higher level. These were formerly utilised as offices and store-rooms, and are well adapted to serve as laboratories for morphological or physiological work. The largest shed has bench and window space amply sufficient for the needs of half a dozen workers. At present there is no supply of running water in connection with any of these outhouses, as the highest of the existing storage tanks lies approximately at the same level as the floor of the large shed, and is only connected to the dwelling-house. But it would be a simple matter to lay down a tank further up the hills, from which pipes could be carried to any of the sheds. Cinchona is fortunate in possessing an almost ideal climate. The annual mean temperature is $62^{\circ} \mathrm{F}$, the mean variation only $12^{\circ} \mathrm{F}$. The rainfall is high, amounting to IO4 in.; but, during the summer months, at any rate, this precipitation chiefly takes the form of heavy thunder-showers, which fall in the middle of the day, and are usually followed by delightfully fresh, sunny evenings. The nights are always cool, and often indeed decidedly cold.

Like the Port Royal Hills, the Blue Mountains are, on their southern side, cultivated up to about $4000 \mathrm{ft}$.; from that level upwards they are clad in a dense covering of virgin forest which extends up to the highest summits. As already stated, the cultivation of Cinchona trees was at one time carried on upon a large scale on the slopes around the Hill Gardens. At the present day scarcely any traces of these plantations remain, and the hillsides are rapidly returning to their natura! condition. A large amount of botanical material of general interest can therefore be collected in the immediate vicinity of the gardens.

A pleasant walk of three miles from Cinchona, along a level path-a rare luxury in these hills-brings one to Morce's Gap, the most frequented pass over the main ridge. Rather more than half-way from Cinchona to the gap, the somewhat scrubby growth covering the site of the old plantations gives place to evergreen dripping-forest of the most luxuriant description. The dominant trees are for the most part thin-stemmed, and of moderate stature. They are set closely together, and the leaf-canopy overhead is very dense. Hence from the greater part of the interior of this forest sunlight is altogether excluded, and even the diffuse illumination is greatly reduced. The undergrowth is on the whole markedly hygrophilous in character. It is everywhere largely composed of shade-loving ferns. In every respect, indeed, ferns constitute a very important and conspicuous element on the forest flora. Alsophilas, Cyatheas, and Hemitelias rear their splendid crowns of foliage on stems 30 or $40 \mathrm{ft}$. in height. Lomarias and Davallias climb high on the tree trunks, or straggle over the bushes. On the steep slopes are groves of the remarkable Lophosoria pruinata, or impenetrable thickets of Gleichenia. The numerous small stony gullies harbour many forms of special interest, such as Marattia alata, Danaea alata, and Pteris, podophylla. Among the rich and varied epiphytic flora of these woods ferns likewise play no mean part, the Hymenophyllaceæ in particular being represented by many exquisite forms. The phanerogamic undergrowth, in so far as it consists of shrubs, is particularly rich in Rubiaceæ and Melastomacer; the commonest herbs are species of Peperomia and Pilea. Climbers are fairly plentiful, but few of them are woody, a notable exception being Marcgravia umbellata, old stems of which attain a very considerable 
orirth. Epiphytes are exceedingly abundant, especially Bromeliads and Orchids, the former excelling in numerical strength, the latter in number of species and variety of form.

There are many excellent collecting grounds in the neighbourhood of Cinchona, such as the valley of the Mabess River to the north, Sir John Peak (both above Newhaven Gap, and below that pass, along the Latimer River), and various localities near Catherine's Peak, as well as the slopes of that mountain itself.

The preceding remarks may have served to give some idea of the merits of Cinchona from a strictly botanical point of view. There are many other places in Jamaica, such as the John Crow Mountains, Holly Mount, Mount Diablo, and, above all, the almost unexplored "cock-pit country," which are undoubtedly rich in botanical interest.

It may be worth while to point out that in regard to such considerations as personal safety and comfort, cost of living, and facilities for transport, Jamaica generally, and Cinchona in particular, compare very favourably indeed with other botanical stations in the tropics. Even in Kingston, the refreshing sea and mountain breezes, and the cool nights, render the heat quite supportable in the height of summer. In fact, Jamaica must be considered distinctly healthy, the death-rate for the whole island having been only 22 per 1000 in I9I2. In the mountains there is no risk of contracting any tropical disease. Anywhere in hot countries the nature of the water supply is a matter requiring the most careful consideration. Cinchona is, however, singularly fortunate in possessing a source of drinking water which is above suspicion. The island is quite free from large carnivora and venomous snakes; indeed, the only noxious animals of any importance, apart from mosquitoes, are scorpions; although ticks are, in some seasons and localities, a source of discomfort.

The double journey, from England to Kingston and back, occupies from four to six weeks, and costs $35 l$. to $55^{l}$. according to the route selected. Any botanist who is prepared to set aside a summer vacation for the purpose can enjoy from seven to nine weeks in this delightful island at a total cost of well under rool. The agreement recently signed for the annual tenancy of the Cinchona Bungalow between the Jamaican Government and a committee of the British Association has had the effect of making the house available for botanists and others. Application for its use may be made (with suitable credentials) to the chairman of the committee (Prof. F. O. Bower, University, Glasgow). Unfortunately, the outbreak of war during the first year of the tenure may prevent the opportunity being used. But the object of this article is to make the fact more fully known, and to show that while the scientific attractions of Cinchona are great, the risks are negligible. Cinchona is probably the safest, as it is also the nearest, point to Great Britain where a tropical flora can be studied in something approaching the virgin state; and a visit of quite useful length can easily be fitted into an ordinary summer vacation.

M. D.

\section{THE AMERICAN PHILOSOPHICAL SOCIETY.}

THE annual general meeting of the American Philosophical Society was held in Philadelphia on April 22-24. The meeting was opened by President W. W. Keen, who, with Vice-Presidents A. A. Michelson, W. B. Scott, and Prof. C. L. Doolittle, presided over the various sessions.

On the evening of April 23 a reception was held in the hall of the Historical Society of Philadelphia, at which Dr. W. M. Davis, emeritus professor of NU. $238 \mathrm{I}$, VOL. 95] geology, Harvard University, gave an illustrated lecture on new evidence for Darwin's theory of coral reefs. The lecture described the chief results of a Shaler Memorial voyage aoross the Pacific in I9I4, with studies of the Fiji group, New Caledonia, the Loyalty Islands, the New. Hebrides, the Great Barrier Reef of Australia, and the Society Islands (see Nature, April 15, p. I89).

On the afternoon of April 24 a symposium was held on the figure, dimensions, and constitution of the interior of the eat th. The subject was discussed from the astronomical point of view by Dr. Frank Schlesinger, dire:tor of Allegheny Observatory, Pittsburgh; from the geological point of view by Dr. T. C. Chamberlin, head of department of geology, University of Chicago; from the seismological point of view by Dr. H. F. Reid, professor of dynamical geology and geography, Johns Hopkins University, Baltimore; from the geophysical point of view by Mr. J. F. Hayford, director of the College of Engineering, North-western University, Evanstown, Ill.

Abstracts of a number of the papers read during the meetings have reached us from Philadelphia, and the following brief résumé has been compiled from them. In the case of most of the papers, the titles alone were given in the report 'sent to us, but we have omitted these as not providing information of interest.

Prof. E. P. Adams, Princeton University: "The Hall and Corbino Effects."

The Hall effect is the production of a transverse difference of potential in a conducting sheet when an electric current flows through it and it is placed in a magnetic field perpendicular to its plane. The Corbino effect is the production of a circular current in a conducting disc when a radial current flows through it and it is placed in a magnetic field perpendicular to its plane. Experiments made to study the latter effect and to show its essential relation to the Hall effect are described. The symmetry of the experimental arrangement for measuring the Corbino effect, as well as the fact that the measurement of the Hall effect requires very thin sheets, gives to the Corbino effect an important position among galvano-magnetic effects.

Dr. C. F. Brush: "Spontaneous Generation of Heat in Recently Hardened Steel."

The author shows that the specimens of carbon tool steel and tungsten "high-speed" steel examined spontaneously generated a considerable amount of heat at the temperature of the room after being waterhardened at cherry-red or white heat. The development of heat at steadily diminishing rate was observable for more than a month, and was accompanied by a shrinkage in the volume of the steel. Progress of heat generation and of shrinking are shown in curves. But that shrinking is only incident to, and is not the prime cause of, the generation of heat, is evidenced by the fact that the internal work represented by the heat generated is hundreds of times greater than necessary to produce the observed change in volume. In the process of hardening, the steels increased at least $\frac{\tau}{2}$ per cent. in volume, as shown by specific gravity tests of $\frac{1}{2}$-in. bars and linear measurements of long thin rods. When afterwards tempered to light-blue colour, much shrinkage took place at once, and another large shrinkage when annealed. The author regards the hardened steel as being in a condition of great molecular strain, somewhat unstable at first. Spontaneous relief of a small portion of the strain causes the generation of heat observed until stability at room temperature is reached. Any considerable rise of temperature, as in tempering, permits a further spontaneous relief of strain, or molecular rearrangement, doubtless accompanied by more generation of heat, and so on until annealing temperature 